\title{
Develop Vision, Ask Questions and Innovate
}

\section{Nair SS*}

Ministry of Health and Family Welfare, Government of India, India

\section{Editorial}

It is presumptuous on my part to address public administrators and managers about developments in their fields. Volumes have been written about these by experts. I venture to draw your attention to a basic phenomenon.

Very often we mechanically hold on to some practices that are in vogue for a long time. Only if we develop an approach of rethinking and action we can come out of the rut in which we have placed ourselves. If we rethink, we will be surprised that we have been blindly following many practices and approaches only because no one has questioned these. Albert Einstein cautioned: "The important thing is not to stop questioning"

To be effective, rethinking and action should lead to innovation which should be based on an enlightened background of vision, imagination and open mind. Importance of each of these has been emphasized by thinkers.

Swami Vivekananda stressed that losing vision is worse than losing eye sight. Albert Einstein said that imagination is more important than knowledge and that true sign of intelligence is not knowledge but imagination." A.P.J. Abdul Kalam late President of India said: “Dream, dream, dream. Dreams transform into thoughts, and thoughts into action.

Having an open mind is important. Mahatma Gandhi exhorted people to keep windows open for ideas to flow in. An anonymous thinker said: "A mind is like a parachute. It works only when it is open"

The need for innovation has been emphasized by thinkers: "We cannot solve our problems with the same thinking we used when we created them." (Albert Einstein); "I dream of things that never were, and ask why not?" - (Robert F. Kennedy)

We can make progress only if we think out of the box and ask lot of questions, discuss these freely and objectively and carry out innovative studies to find proper answers. While asking questions we should not take the attitude of a frog in the well, for which universe consists of the well only?. We have to ask lot of questions within and beyond the well, with an open mind and without being influenced by any pressure groups or pressure of imagined circumstances. Boldness has genius, power and magic in it. (Goethe). We should find innovative solutions for problems on the wrong track and stabilize those on the right track.

Some glaring examples of lack of vision and innovation are discussed in a series of articles entitled "Let us Think and Act with an Open Mind to Develop a Vibrant Democracy" published in the blogs http://letusrethink.blogspot.in/- and http://letusthinkoutofthebox. blogspot.in/-. These include an election system which does not give voice to majority of people; politicians supervising professionals, without necessary qualifications; a judicial system which delays justice for years and demeans experienced judges by questioning their capability to independently study all aspects of cases and provide justice without interference by lawyers; practice of religion which has often led to disturbance of peace, loss of brotherhood, intolerance of other religions, conflicts and even war; an education system which

fails to promote originality in thinking, dovetailing of aptitude with professionalism and preparing citizens with competence to face realities of life; a health care system which has failed to meet the needs of common people; media without adequate vision; and a suggestion to be realistic, accept that inequalities are natural and fix suitable limits for inequalities to avoid doing lip service to equality.

Some examples of lack of vision to find innovative solutions in a scientific field, which led to colossal over diagnosis and large scale unethical treatment which affected millions of people, are discussed in an article "Ethical aspects of the Revised National Tuberculosis Control Programme" published in Indian Journal of Medical Ethics 2011 (AprJun:8(2)102-6).

Cultural groups all over the world practice different types of rituals. If we focus on any one of them it will be clear that it is practiced only by a negligible minority of people in the world and the majority who do not practice it has not come to any harm. These continue without being questioned.

Public administrators and managers ought to develop a background of vision, imagination and open mind, ask questions "within and beyond the well" and apply innovative solutions. This is the way they can contribute to development of a better world for us to live in. They ought to recognize that they owe this to society and fulfill their "corporate responsibility". Then they can be proud of their all-round achievements.

*Corresponding author: Nair SS, Retd. Director, (Evaluation) Ministry of Health and Family Welfare, Government of India, India, Tel: 040 23061647; E-mail: forte.nair@gmail.com

Received September 18, 2015; Accepted September 21, 2015; Published September 23, 2015

Citation: Nair SS (2015) Develop Vision, Ask Questions and Innovate. Review Pub Administration Manag 3: e106. doi:10.4172/2315-7844.1000e106

Copyright: @ 2015 Nair SS. This is an open-access article distributed under the terms of the Creative Commons Attribution License, which permits unrestricted use, distribution, and reproduction in any medium, provided the original author and source are credited. 